\title{
The Covid-19 Pandemic and the Challenge of Teaching English Online in Higher Institutions of Learning in Cameroon
}

Blasius Agha-ah Chiatoh ${ }^{1}$ and Jude Kaki Chia*2

${ }^{1}$ Chair, Department of Linguistics, University of Buea, Cameroon

${ }^{2}$ PhD Candidate of Applied Linguistics, Department of Linguistics, University of Buea, Cameroon

Corresponding Author: Jude Kaki Chia, E-mail: chia.jude@ubuea.cm

\section{ARTICLE INFORMATION}

Received: November 02, 2020

Accepted: December 10, 2020

Volume: 2

Issue: 5

DOI: 10.32996/jeltal.2020.2.5.4

\section{KEYWORDS}

Covid19, Lockdown, E-Learning, Internet-based Tools, Teaching English

\section{ABSTRACT}

The resources of the internet have long served the English language teaching enterprise with varying levels of implementation and success. The Covid19-imposed lockdown in March, 2020 and the Prime Ministerial decision for higher institutions of learning in Cameroon to switch to online lectures fazed many staff, including those on the Use of English programmes in state universities. This study set out to describe Use of English teachers' views about the place of the internet in English language instruction as well as their online teaching experiences during the Covid19-imposed lockdown. A questionnaire survey was used to elicit data from thirty Use of English staff affiliated to the Universities of Buea and Bamenda. The findings highlight English language teachers' firm belief in the potential of internet-based tools to facilitate not only English language learners' display of 21st century learning skills but English language skills as well. However, not much success regarding the integration of the various internet-based tools was acknowledged. Limited Information and Communication Technology competence, lack of adequate training on how to teach online, poor internet connection, power failures, and high costs of internet subscription, were amongst the challenges enlisted by the subjects in this study. We recommend the effective integration of E-Learning as a post-pandemic pedagogy for Use of English staff in both universities under study.

\section{Introduction}

Most professions in the $21^{\text {st }}$ Century, including the teaching of English as a Second Language (ESL) rely on the internet. As the most highly sought-after language, English is increasingly being taught through the use of internet-based tools. For instance, activities such as lesson preparation, lesson delivery, and feedback provision are carried out through internet-based tools such as emails, telnet and the World Wide Web (WWW) to mention but these. The importance of using the internet in the teaching of English has been attested in a number of studies. Some of these advantages include the effective evaluation of teaching and learning strategies (Kornum, 1993), improvements in learners' writing, specifically, fluency and organization (Davis \& Chang, 1994), increased participation in classroom discussions (Warschauer, 1996b), and greater autonomy for learners (Osuna \& Meskill, 1998). The importance of using internet-based tools in the teaching as well as learning of English is so profound that approaches such as Computer Assisted Language Learning (CALL) have become popular. CALL is generally used to describe the various processes and activities that use computers in the teaching and learning of a new language (Warschauer, 1996). In most cases, these computers are used to access various internet-based tools that facilitate language teaching and learning. E-learning is also a related term that is frequently used when discussing the use of technology in language teaching and learning. It refers to the educational model that is based on the use of electronic media and devices as tools for improving access to training, communication and interaction. Unlike regular textbooks, E-learning provides a richer treasure for the improvement of language skills (Cai, 2012).

K C AL-KINDI CENTER $\mathbf{R}$ D FOR RESEARCH Your gateway to world-class research
Published by Al-KindiCenter for Research and Development. Copyright (c) the author(s). This is an open access article under CC BY license (https://creativecommons.org/licenses/by/4.0/) 
The government of Cameroon especially through its Ministry of Higher Education has not been indifferent to the importance and role of the internet and its tools in the teaching of English in higher education. This is reflected in a number of measures carried out across the years. In his address to the youths in 2001, the President of the Republic of Cameroon called for the orientation of education towards the knowledge economy. This call led to the introduction of ICTs in secondary schools and the subsequent provision of regular presidential grants in the form of Multimedia Resource Centres with internet connection (Mbangwana, 2008). State universities in Cameroon have Computer or IT centres where students can easily access the internet especially for research and study purposes. In 2016, the President of the Republic of Cameroon also donated 500.000 computers to students in both state and private universities in Cameroon. The goal was to ease research, encourage E-learning and facilitate the integration of the youths into the digital economy. In addition to availing computers to students in higher education in Cameroon, the administrations in state universities have proceeded to striking partnership deals with various Internet Service Providers (ISPs) aimed at providing access to the internet for students on campus (Josué, 2007). In addition to these computers and internet access at the institutional level, most students in higher education own smart phones with which, thanks to partnerships with telecommunication companies such as CAMTEL, MTN, ORANGE, and NEXTELL, they can access the internet at subsidised rates. In fact, in the Cameroon Head of State's Message to Cameroonian youths in February, 2016, he referred to the youths as an 'android' generation. This was a testament to Cameroonian youths' reliance on digital devices with which they explore the internet.

Figure1: Sample of internet boosters at the University of Buea Campus (A) and sample of laptops donated to students in higher institutions of learning in Cameroon (B)

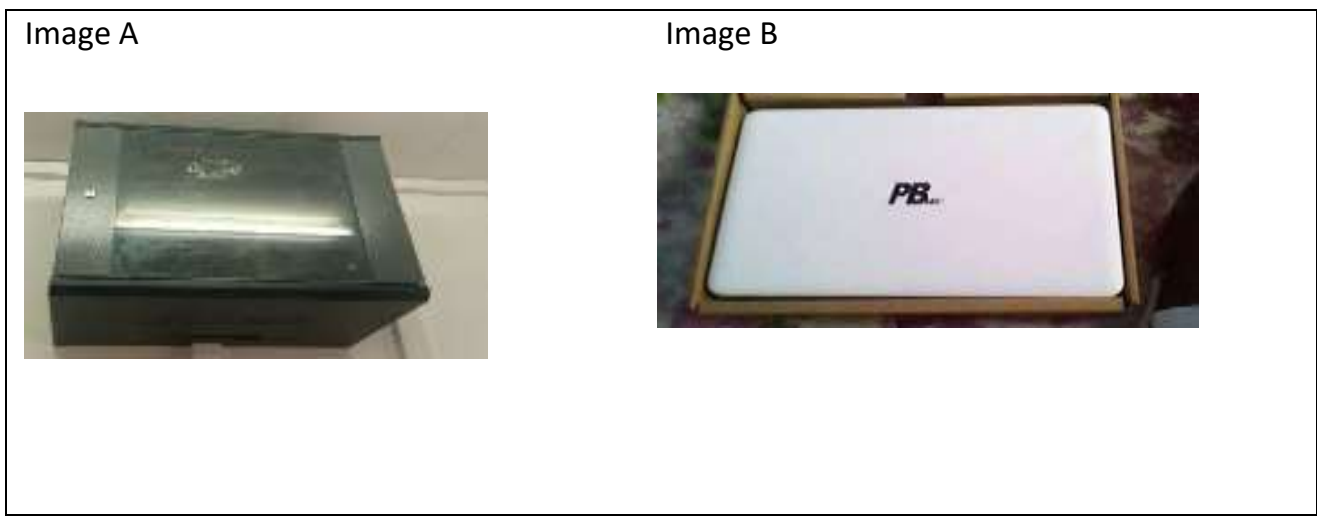

The availability of digital devices and access to the internet for both staff and students in, at least, all state universities in Cameroon, implies the potential for possible online studies through virtual platforms. As reported by McEwan, (2001), webbased course offerings have witnessed an increase in most universities and colleges. However, most state universities in Cameroon neither effectively offer online courses nor fully integrate E-learning through the use of internet-based tools, as part of their teaching and learning options. In March, 2020, the World Health Organisation (WHO) declared the Corona Virus (Covid-19), a pandemic (Miller \& Brueck, 2020). As part of the social distancing measures stipulated by the WHO, all schools including university campuses in Cameroon like elsewhere were required to shut down. Two months afterwards, the Prime Minister of Cameroon alongside the Minister of Higher Education sanctioned the commencement of online lectures for university students. This swift change from face-to-face lectures to online studies was built on the expectation that the different universities would use the available digital resources (ICTs and internet access) to implement this change. As noted by Baral (2020), Covid19 was both an unprecedented and unintended global pandemic which triggered a shift from a face-toface to an online-based system of education.

Because the Ministry of Higher Education did not specify which internet-based tools to use, it was up to the universities and faculties to decide which tool(s) worked best for them. In the University of Buea, for instance, the Use of English Programme adopted Google Classroom and Zoom, while the University of Bamenda opted for my Moodle and zoom. Prior to implementation, staff of the Use of English programme underwent a one-day drilling exercise on how to begin second semester lectures online. The students on the other hand were encouraged to stay at home and use their devices (laptops and smartphones) to access lectures online. Though there was no quick fix for possible power disruptions intimated by some stakeholders, steps were taken to ensure that internet access, at least, was not a major issue. 
In line with their partnerships with state universities and higher institutions of learning in Cameroon, the four internet service providers in Cameroon made moves to subsidise internet costs to sustain learning at home. For instance, while MTN Cameroon, through the MTN Foundation provided free access to many online learning platforms, Orange Cameroon subsidised internet use by $30 \%$ for all residential internet bundles. On their part, Nexttel Cameroon sustained its pre-existing students' internet promotional bundles (FLY student), while Camtel offered up to150 gigabytes of internet data for just FCFA 10.000 to encourage social distancing).

Figure 2: Evidence of Covid19-induced internet subsidization for the four Internet Service Providers in Cameroon

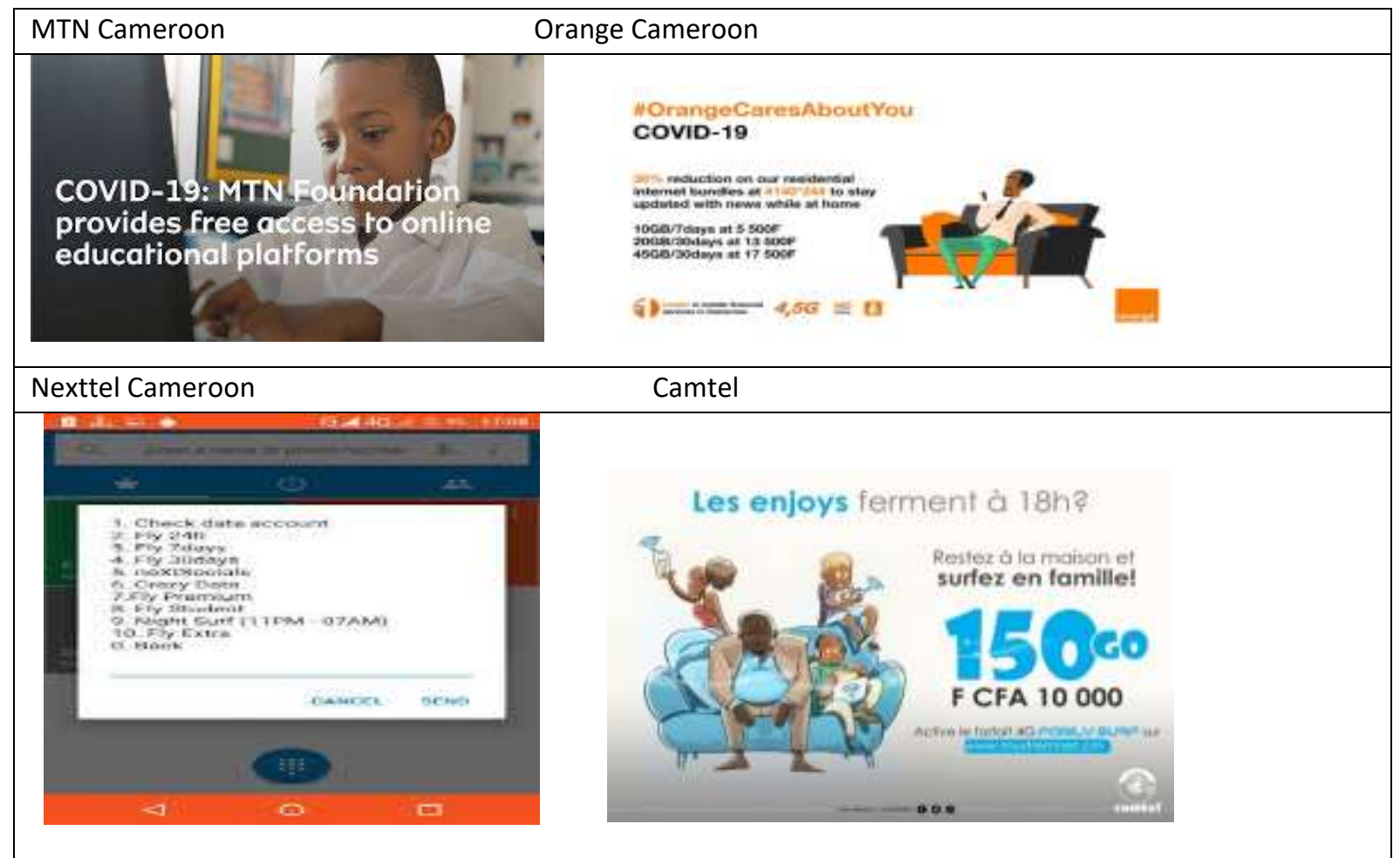

Source: MTN Cameroon, Orange Cameroon, Nexttel Cameroon, and Camtel, respectively

The online teaching experiment lasted one month, during which time it was observed that the staff from the various departments and faculties across state universities displayed unequal levels of commitment and interest in teaching online. Most staff of the Use of English Programme, for instance, were reluctant to use the prescribed internet-based tools despite the scratch training received on how to use these. The problem had to be beyond the availability of digital devices (laptops, desktops, smart phones) and access to the internet. This prompted this action research which set out to answer the following questions:

1. To what extent do University English Language teachers consider the internet useful in improving English language pedagogy?

2. How often did University English Language teachers integrate internet-based tools during the Covid19-induced lockdown?

3. What challenges were faced by University English Language teachers of English during the Covid19-induced lockdown?

\section{Method}

This study set out to collect both numerical and non-numerical data to account for Use of English teachers' experiences with the use of internet-based tools during the Covid19-imposed lockdown. This study used the action research model which according to Johnson (2012) is suitable for studies aimed at investigating an authentic school (or classroom) problem or situation, with the goal of improving practice. The school problem in the current study is English language teachers' lack of commitment towards integrating internet-based tools during lectures within the Covid19-imposed lockdown period. Given the nature of the data sought, a descriptive research design was deemed well suited for this study. As acknowledged by Polit 
\& Hungler (1999), the goal of descriptive research is to observe, describe as well as document aspects of a naturally-occurring situation.

Data in this study were obtained from a largely close-ended questionnaire administered to Use of English teachers at the Universities of Buea and Bamenda, Cameroon, where English is the language of instruction for well over $90 \%$ of the courses taught. The questionnaire comprised four sections. While section 1 sought to elicit demographic information such as age, sex and longevity, section 2 included prompts designed to establish respondents' perceptions regarding the suitability of internet-based tools as far as improving learning skills in general and language skills, in particular, are concerned. Section 3 dwelled on the frequency with which the teachers under study used some internet-based tools to teach English during the Covid19-imposed lockdown. The last section sought to ascertain the measure of success with which Use of English was taught during the lockdown period, as well as what they perceive to be the challenges experienced thereof. While the first three sections and part of section 4 were designed to procure numerical data, part of section 4 was designed to elicit nonnumerical data (other challenges encountered using internet-based tools to teach English online).

In all, 30 Use of English teachers took part in this study- 20 from the University of Buea and 10 from the University of Bamenda. Regarding sex, there was a total of $16(53.3 \%)$ males and $14(47.7 \%)$ females. While $10(33.3 \%)$ respondents had work experiences ranging from 1-5 years, 11 (36.7\%) of them had work experiences ranging from 6-10, and only 9 had more than 10 years of work experience. Due to the enforcement of social distancing measures, the questionnaire was administered online with steps taken to circumvent the duplication of responses. The numerical data were analyzed using simple frequencies while the non-numerical data were analyzed thematically. Where the non-numerical responses provided aligned with pre-established themes, these were simply added to the themes and computed.

\section{Results}

The data obtained from the questionnaire survey highlights the importance of the internet in the improvement of learning skills in general and English language skills in particular. With respect to general learning skills, most (between16-22) of the teachers agreed that using the resources of the internet in the teaching process can augment learners' general learning skills such as critical thinking, creative thinking, communicating and collaborating. This agreement was also expressed by a majority (between 21-27) of the teachers regarding the potential of the internet to be used to improve the writing, reading, speaking, listening and vocabulary skills of learners of English. Table 1 below provides a snapshot of the views expressed by the teachers in this study.

Table 1: The internet and the improvement of general learning and English language skills

\begin{tabular}{|l|l|l|l|}
\hline Skills & Agree & Disagree & Undecided \\
\hline General Learning Skills & & & \\
\hline $\begin{array}{l}\text { Critical thinking (Including but not limited to the ability to carefully } \\
\text { analyse or understand something) }\end{array}$ & 21 & 1 & 8 \\
\hline $\begin{array}{l}\text { Creative thinking (Including but not limited to the ability to invent } \\
\text { and discover possibilities) }\end{array}$ & 22 & 1 & 7 \\
\hline $\begin{array}{l}\text { Communicating (Including but not limited to the ability to analyse } \\
\text { a situation, choose a medium, evaluate messages, follow } \\
\text { conventions, and take turns) }\end{array}$ & 22 & 1 & 7 \\
\hline $\begin{array}{l}\text { Collaborating (Including but not limited to the ability to brainstorm } \\
\text { as part of a group, evaluate and take decisions }\end{array}$ & 16 & 4 & 10 \\
\hline English Language Skills & & \multicolumn{2}{|l|}{} \\
\hline Improve writing skills & 23 & 4 & 3 \\
\hline Improve reading skills. & 26 & 3 & 1 \\
\hline Develop speaking skills & 21 & 2 & 7 \\
\hline Develop listening skills. & 21 & 4 & 5 \\
\hline Improve vocabulary & 27 & - & 3 \\
\hline
\end{tabular}

The second objective in this study was to establish the frequency with which the teachers under study integrated the various internet-based tools to teach English online during the Covid19-imposed lockdown. As indicated on Table 2, most (49\%) of 
the teachers made frequent use of the various internet-based tools considered in this study. Meanwhile, a few (32\%) of them used them rarely and only a handful (27\%) claimed to have never used any of the tools to teach English during the Covid19-imposed lockdown period. Interestingly, Social media applications such as WhatsApp and Teaching based applications such as Google Classroom and My Moodle emerged as the most frequently used internet-based tools. This is probably because while WhatsApp is one of the most downloaded applications and is easy to send and receive data on mobile devices such as smartphones, the Universities under study patronised teaching-based applications such as Google Classroom and My Moodle for online lectures. Previous experience and institutional requirements could therefore explain the frequency of use of these internet-based tools.

Table 2: Frequency of the integration of internet-based tools in the teaching of English online

\begin{tabular}{|l|l|l|l|}
\hline Internet-based tools & Frequently & Rarely & Never \\
\hline The World Wide Web & $\mathbf{1 0}(33.33 \%)$ & $\mathbf{1 3}(43.33 \%)$ & $\mathbf{7}(23.33 \%)$ \\
\hline Mailing sites such as Yahoo and Gmail & $\mathbf{1 5}(50 \%)$ & $\mathbf{1 0}(33.33 \%)$ & $\mathbf{5 ( 1 6 . 6 6 \% )}$ \\
\hline Video sites such as YouTube & $\mathbf{9 ( 3 0 \% )}$ & $\mathbf{1 1}(36.66 \%)$ & $\mathbf{1 0}(33.33 \%)$ \\
\hline Social media applications such as WhatsApp & $\mathbf{2 3}(76.66)$ & $\mathbf{5}(16.66 \%)$ & $\mathbf{2}(6.66 \%)$ \\
\hline $\begin{array}{l}\text { Teaching-based applications such as Google } \\
\text { Classroom, My Moodle }\end{array}$ & $\mathbf{1 7}(56.66 \%)$ & $\mathbf{1 0}(33.33 \%)$ & $\mathbf{3 ( 1 0 \% )}$ \\
\hline Total & $\mathbf{7 4}(49.33 \%)$ & $\mathbf{4 9}(32.66 \%)$ & $\mathbf{2 7}(18 \%)$ \\
\hline
\end{tabular}

Despite the high frequencies with which the subjects in this study claimed to use the various internet-based tools, this was not consistent with the levels of success of the use of these tools for online teaching. In fact, no subject under study rated the success of online teaching of English during the Covid19-imposed lockdown as excellent. As revealed on Table 3, up to 14 (46.7\%) teachers rated the implementation of online teaching of English during the lockdown as fair and only 8 subjects rated it as good. This perception bespeaks the need to investigate the problems faced while implementing online lectures for the Use of English Programme in both universities under study.

Table 3: Success level of the implementation of online teaching of Use of English

\begin{tabular}{|l|l|l|}
\hline Level of Success & Number & Percentage \\
\hline Excellent & - & - \\
\hline Good & 8 & 26.7 \\
\hline Fair & 14 & 46.7 \\
\hline Poor & 8 & 26.7 \\
\hline Total & $\mathbf{3 0}$ & $\mathbf{1 0 0 \%}$ \\
\hline
\end{tabular}

Finally, the anticipated challenges to teaching Use of English online as acknowledged by teachers in this study ranged from low ICT competence, Lack of adequate training on how to teach online, Cost of internet subscription, the cost of digital devices, poor internet connection, power failures, and poor learner attendance. As detailed on Table 4, the preceding factors constituted a major challenge for most (between10-27) of the teachers under study. On the contrary only between 5-12 teachers considered the enlisted challenges as minor. Some subjects also mentioned challenges beyond those initially included in this study. These include factors that relate to assessment ("It was difficult to give individual tests and exams to students", "Evaluating the learners as individuals or as a group was almost impossible"), laziness on the part of learners ("Students mostly did copy and paste"), and learners' disinterest in online lectures ("...A few who registered did not bother to participate in the lessons").

Table 4: Challenges faced during online teaching of Use of English

\begin{tabular}{|l|l|l|l|}
\hline Type of challenge & \multicolumn{3}{|l|}{ Severity of the challenge } \\
\cline { 2 - 4 } & $\begin{array}{l}\text { Major } \\
\text { challenge }\end{array}$ & $\begin{array}{l}\text { Minor } \\
\text { challenge }\end{array}$ & $\begin{array}{l}\text { Not a } \\
\text { challenge }\end{array}$ \\
\hline $\begin{array}{l}\text { Low ICT competence prior to the covid19-induced online } \\
\text { teaching }\end{array}$ & 10 & 11 & 9 \\
\hline Lack of adequate training on how to teach online during & 13 & 12 & 5 \\
\hline
\end{tabular}




\begin{tabular}{|l|l|l|l|}
\hline the Covid19-imposed lockdown & & & \\
\hline Cost of internet subscription & 16 & 11 & 3 \\
\hline Cost of digital devices & 15 & 12 & 3 \\
\hline Poor internet connection & 27 & 3 & - \\
\hline Power failures & 19 & 11 & - \\
\hline Poor learner attendance & 24 & 5 & 1 \\
\hline Mean & & & \\
\hline
\end{tabular}

\section{Discussion of Findings}

For learners to succeed in the $21^{\text {st }}$ century, they need to wield distinct learning skills. According to Stauffer (2020) the four most important learning skills are critical thinking, creativity, collaboration, and communication, otherwise known as the four C's. This study has established the connection between learning English online and the ability to evince these learning skills. This was acknowledged by most (between16-22) of the 30 teachers of Use of English sampled in this study. With focus on critical thinking, Herrmann (2015) has noted that though one does not need to be articulate in a language to be able to think critically, the task of teaching critical thinking in a language learners do not understand is often daunting. While the current study does not dwell on if/how teachers of English foster critical thinking skills, it does highlight English language teachers' belief that teaching English online can foster critical thinking amongst other $21^{\text {st }}$ century skills. This is possible when one considers the range of skills needed to undertake teaching/learning online. Using the various internet-based tools like WhatsApp, for instance, could afford learners opportunities to communicate and collaborate with fellow course mates, as well as creatively design ways of assessing content learnt. As reported by Hamad (2017), using WhatsApp can not only facilitate the development of English learning skills but improve their 'sharing' experiences.

The potential of the various internet-based tools identified in this study to improve the English language skills of learners was attested by most (between21-27) of the 30 respondents recruited in this study. This aligns with most findings in previous studies. Hani (2014), for instance, reported a significant difference between the overall pretest and posttest writing and vocabulary scores of learners following the use of WhatsApp groups for English language learning as an intervention. Similarly, Andújar-Vaca et al (2017) found that using mobile instant messaging applications such as WhatsApp significantly improved the oral proficiency of English language learners in the experimental group. However, using internet-based tools such as WhatsApp to teach English is not without shortcomings. Some of these according to Hamad (2017) include the task of preparing material, non-respect of class schedules, non-participation on the part of students, the tendency by learners to indulge in copy and paste, and indiscipline.

In line with English language teachers' beliefs about the potential for online to enhance English language learning skills, most (49.33\%)) of the teachers claimed to use these tools frequently. In a study of Nepalese ESL teachers' integration of ICTs in rural schools, Poudel (2018) found that teachers did integrate ICTs in their teaching of English, the challenges notwithstanding. In the same light, Attamimi and Yafaei (2019) have investigated English as a Foreign Language (EFL) teachers' integration of My Moodle in their practice and found that despite the implementation challenges, this teaching application was considered suitable for EFL instruction. The benefits of integrating technology in general in the language teaching and learning process has been documented. According to Jahan (2019), learning enhanced by technology makes teaching tasks simpler, flexible and creates a conducive environment for learning. This view is supported by Alkamel and Chouthaiwale's (2018) assertion that using both web-based and non-web-based ICT tools can promote the teaching and learning of EFL and provide real opportunities for individualized instruction.

Though the teachers in this study claim that they frequently integrated the various internet-based tools to teach English online during the lockdown period, none of them described online teaching during this period as excellent. Rather, up to 14 (46.7\%) of them described the success level as fair and only $8(26.7 \%)$ described it as good. The reasons advanced for the poor implementation of online teaching using the various tools under study were linked to the lack of technological knowledge, poor training, the prohibitive cost of internet and digital devices, poor internet connection, power failures, and poor learner attendance. In a similar study of 30 ESL teachers in secondary and higher institutions of learning across Cameroon, Lando, (2018) noted that technophobia, lack of equipment and deficient technological awareness impaired English language teachers' ability to take advantage of the benefits of technology in the English language teaching enterprise. These and the other challenges identified in the current study resonate with those reported in other ESL contexts. According to Poudel (2018), low ICT competence, cost of technology and lack of internet facilities in rural areas are amongst the 
challenges of integrating ICTs in the teaching of ESL in rural Nepal. In a similar study, internet connectivity, deficiency of resource material, and lack of technology have been identified as the key challenges that beset virtual teaching of ESL in Pakistan during the Covid19-imposed lockdown (Shahzad, et al, 2020). The scope and recurrence of these challenges in a variety of contexts speaks to their gravity. Integrating ICT into the teaching of English is particular daunting partly because of the specificity of the skills required to use ICTs as teaching aids (Salehi \& Salehi 2012). While teachers and students may use some ICTs tools for different purposes, deploying these tools and resources for teaching and learning has left many a challenge in its wake. Chia (2020), has acknowledged that teachers of English in nonnative contexts such as Cameroon face many challenges. But with an augmentation of English Language teachers' ICT skills, some of these can be addressed.

\section{Conclusion}

The resources of the internet have generally been esteemed in the English Language Teaching enterprise. While the internet in particular and ICTs in general have long been integrated in the teaching and learning of English, this has not been the case in low-resource contexts such as Cameroon. Nonetheless, investment moves have consistently been made by the government of Cameroon as far as ICTs in education is concerned. These moves have often taken the form of provision of equipment, subsidization of internet costs and training of personnel. The Covid19 pandemic, however, provided an avenue for the teachers and learners of English in higher education to integrate the various internet-based tools to sustain teaching and learning on different online platforms. The limited success reported in the implementation of online teaching during the Covid19-imposed lockdown period is a testament of the severity of the challenges faced by Use of English teachers in the two Anglo-Saxon universities in Cameroon. While these challenges are not limited to Cameroon, there is a need for English language teaching stakeholders in Cameroon to proactively embrace E-learning as a post-pandemic pedagogy in conjunction with traditional face-to-face lectures. This is because with or without a lockdown-inducing pandemic, such as Covid19, the non-integration of ICTs and internet-based tools would deprive the learners and teachers of English in higher education in Cameroon, of the numerous advantages afforded by e-learning. In the long run and in case of a prolonged lockdown, the nonintegration of internet-based tools to teach English could have economic implications for English Language teachers through the possible loss of job opportunities that place a premium on ICT competence. While the absence of power and the internet especially in rural areas in Cameroon may not have a quick fix, the prevalence of ICT incompetence amongst teachers of English in urban areas such as those in higher education, is the elephant that must no longer be contained in the room of English language teaching in Cameroon.

\section{Acknowledgement}

We are grateful to all the Use of English staff of the Universities of Buea and Bamenda, who volunteered to take part in this study.

\section{References}

[1] Alkamel, M. A. A., \& Chouthaiwale, S. S. (2018). The use of ICT tools in English language teaching and learning: A literature review. Veda's Journal of English Language and Literature-JOELL, 5(2), 29-33.

[2] Andújar-Vaca, A., \& Cruz-Martínez, M. S. (2017). Mobile instant messaging: WhatsApp and its potential to develop oral skills. Media Education Research Journal, 25(50), 43-52. https://doi.org/10.3916/C50-2017-04.

[3] Attamimi, R., \& Yafaei, Y. I. (2019). Understanding teachers' integration of moodle in EFL classrooms: A case study. English Language Teaching, 12(4), 1-6.

[4] Baral, R. P. (2020). ELT in Covid pandemic: Crisis, opportunities, and responses. NELTA ELT Forum. https://neltaeltforum.wordpress.com/2020/07/31/

[5] Cai, H. (2012). E-learning and English teaching. International Conference on Future Computer Supported Education. Huiwei Cai / IERI Procedia, $841-846$.

[6] Chia, J. (2020). Towards a cross-curricular awareness for ESL teachers in Cameroon. Journal of Linguistics and Foreign Languages,1(2),7-18. Retrieved from https://royalliteglobal.com/jlfl/article/view/297.

[7] Published Hamad, M. (2017). Using WhatsApp to enhance students' learning of English language "Experience to Share". Higher Education Studies, 7(4), 74-87.

[8] Hani, N. A. B. (2014). The impact of WhatsApp group's utilization of EFL students' vocabulary writing amelioration. International Journal of University Teaching and Faculty Development, 5(2), 73-87.

[9] Hermann, E. (2015). The four C's of 21st century learning for ELLS: Critical thinking. http://exclusive.multibriefs.com/content/.

[10] Jahan, M. (2019). Advantages of Computer Information Systems/Multimedia Technology in English Language Teaching. 3(12), 2019, www.jrspelt.com.

[11] Josué, T. T. (2012). ICT in education in Cameroon. Survey of ICT and Education in Africa: Cameroon Country Report. www.infodev.org/ict4edu-Africa. 
[12] Kornum, L. (1993). Foreign language teaching and learning in multimedia environment. Calico Journal, 10(3), 65-76.

[13] Lando, R. (2018). Technology in the ELT Industry in Cameroon: When old habits die hard. Journal of Strategic and International Studies. XIII(1), 43-50.

[14] Mbangwana, M. A. (2008). Introduction of ICT in schools and classrooms in Cameroon. In K. Toure, T. M. S. Tchombe, \& T. Karsenti (Eds.). ICT and Changing Mindsets in Education. Bamenda, Cameroon. Langaa; Bamako, Mali: ERNWACA / ROCARE.

[15] McEwan, B. (2001). Web-assisted and online learning. Business Communications Quarterly, 64(2), 98-103.

[16] Miller, A. M., \& Brueck, H. (2020). World Health Organization declares the coronavirus a pandemic. https://www.businessinsider.com/who-declares-coronavirus-pandemic-covid19-2020-3

[17] Osuna, M. M., \& Meskill, C. (1998). Using the World Wide Web to integrate Spanish language and culture: A pilot study. Language Learning and Technology, 1(2), 71-92.

[18] Polit, D. F., \& Hungler, B. P. (1999). Nursing research: Principles and methods (6th ed.). Lippincott.

[19] Poudel, G. P (2018). Integrating ICTs in English language teaching: Teachers' perception, strategies and challenges. NELTA ELT Forum. https://neltaeltforum.wordpress.com/2018/01/07/

[20] Salehi, H., \& Salehi, Z. (2012). Integration of ICT in language teaching: Challenges and barriers. Proceedings of the 3rd International Conference on e-Education, e-Business, e-Management and e-Learning, 27, 215-219.

[21] Shahzad, S. K., Hussai, J., Sadaf, N., Sarwat, S., Ghani, U., \& Saleem, R. (2020). Impact of virtual teaching on ESL learners' attitudes under Covid-19 circumstances at Post Graduate level in Pakistan. English Language Teaching, 13(9), 1-9.

[22] Stauffer, B. (2020). What Are the 4 C's of 21st century skills? https://www.aeseducation.com/blog/four-cs-21st-century-skills.

[23] Warschauer, M. (1996b). English teachers, prepare yourselves for the digital age. TESL-EJ., 2(1), 1-6. 